\title{
Canine Leishmaniosis: tools for diagnosis in veterinary practice in Colombia
}

\section{Leishmaniosis canina: herramientas para el diagnóstico en la consulta veterinaria en Colombia}

\author{
Víctor Acero $\mathrm{P}_{1}^{1 *} \mathrm{DMV}$, Perla Ángel $\mathrm{B}_{r^{2}} \mathrm{DMV}$, Esther Fonseca $\mathrm{B},{ }^{3} \mathrm{DMV}$, \\ Lluís Ferrer, ${ }^{4}$ Ph.D, Xavier Roura, ${ }^{5}$ Ph.D.
}

\begin{abstract}
${ }^{1}$ Asociación Nacional de Médicos Veterinarios de Colombia (AMEVEC), Bogotá, Colombia. ${ }^{2}$ Clínica Protectora de Animales, Bogotá, Colombia. ${ }^{3}$ Clínica Veterinaria Animaux S.A.S., Bogotá, Colombia. ${ }^{4}$ Tufts Cummings School of Veterinary Medicine, Department of Clinical Sciences, 200 Westboro

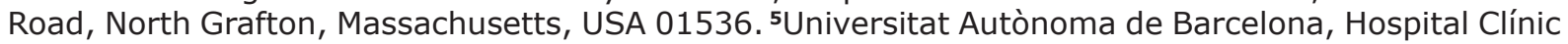
Veterinari, Bellaterra 08193, Barcelona, Spain.*Correspondencia: sepulvic@gmail.com.
\end{abstract}

Received: March 2015; Accepted: June 2015.

\begin{abstract}
The objective of this article is to perform a critical analysis and guide veterinarians in the management of canine Leishmaniosis. A systematic literature review was performed between 2005 and 2014 including scientific papers which take into account experiences and reports of: pathogenesis, diagnosis, clinical presentation, treatment, vaccination, prevention and control strategies. We discuss the different aspects of VL management and aspects that should be taken into account depending on the country, after a patient is suspected or confirmed as positive, including the possibility of euthanasia. We describe the different clinical manifestations of the disease, diagnosis, signs and treatment of canine leishmaniosis. Canine leishmaniosis is present in different parts of the country, therefore it must be considered as a possible differential diagnosis in the veterinary clinic, in patients with dermatological and systemic signs that are compatible with various diseases. In Colombia, the patients diagnosed with cutaneous leishmaniasis could be treated and have a favorable prognosis, whereas in canines with diagnosis of visceral leishmaniasis euthanasia should be considered because of the public health implications.
\end{abstract}

Key words: Diagnosis differential, leishmania, reservoirs, zoonoses (Source: DeSC).

\section{RESUMEN}

Se realiza un análisis crítico con el fin de orientar a los médicos veterinarios en el tema de Leishmaniosis canina. Se realizó una revisión de literatura a partir del año 2005 de manera sistemática considerando artículos científicos donde se tuvieran en cuenta experiencias y reportes de la patogenia, diagnóstico, presentación clínica de la enfermedad, tratamiento, la vacunación, el abordaje de los casos, estrategias de prevención y control y las consideraciones que se deben tener, según el país, ante la sospecha o confirmación de un paciente positivo, entre estos aspectos, la eutanasia. Se presentan las diferentes manifestaciones clínicas de la enfermedad, el diagnóstico, los signos y tratamiento de un paciente sospechoso para leishmaniosis canina, a manera de orientación para el profesional de la clínica veterinaria. La leishmaniosis canina se encuentra presente en diferentes partes del país, por lo que debe considerarse como posible diagnóstico diferencial en la clínica veterinaria, en pacientes con signos dermatológicos y sistémicos que son compatibles con diversas enfermedades. En Colombia, los pacientes diagnosticados con leishmaniosis cutánea podrían ser tratados y tener un pronóstico favorable, mientras que en los caninos con diagnóstico de leishmaniosis visceral debe considerarse la eutanasia por las implicaciones en salud pública.

Palabras clave: Diagnóstico diferencial, leishmania, reservorios, zoonosis (Fuentes: DeSc). 


\section{INTRODUCTION}

Leishmaniasis is a disease that is transmitted to human beings and animals by vectors. It is caused by protozoan parasites of the genus Leishmania. Canines are susceptible to acquire a visceral form and cutaneous form ( $L$. braziliensis, L. panamensis) and are the main reservoir for Leishmania infantum, the causative agent of the visceral form in humans. The visceral canine leishmaniosis is a chronic infection that can cause death to animals. It is endemic in several countries in Latin America, the Mediterranean and Africa. It is considered as a severe problem both for public health as well as for the veterinary doctor. The prognosis in animals is worse than in humans due to the difficulties and to the inefficiency of the treatment, which leads to the decision to sacrifice positive animals. In endemic places there is a particularly high number of human cases and little availability of alternative therapies (1).

This disease is one of the main zoonotic diseases recognized at a global level, with a fatal prospective for human beings and animals. Canines are the main reservoir or source of infection for humans. At the hospital there are a number of symptoms and degrees of severity that appear. Currently there is a unified consensus about the management of the disease (2).

The disease is transmitted to mammals through female sand-fly bites naturally infected. The geographic distribution of leishmaniasis is limited to the distribution of the genus Lutzomyia vectors, which are responsible for the transmission of the disease in America and those of the genus Phlebotomus, which are responsible for the transmission of the disease in the old world (Europe, Asia and Africa) (3). There are three main types: Cutaneous (most common), Mucocutaneous and Visceral (considered the most severe, also known as kala-azar) (4). In Colombia, according to the National Health Institute (INS), there has been an increase in the number of cases of cutaneous Leishmaniasis, a disease that is considered endemic in almost all of the national territory, except San Andres Islands, Bogota and Atlantico. It is believed that there are more than 10 million people at risk of transmission, considering as sources those which coincide with the distribution of the vector in the departments of Tolima, Huila, Cundinamarca, Bolivar, Cordoba, Sucre, Santander and Norte of Santander and Norte de Santander, among others (5).

Players of the armed conflict in the country are widely exposed to the bite of Lutzomyia. Members of the armed forces that are deployed to red combat

\section{INTRODUCCIÓN}

La Leishmaniosis es una enfermedad transmitida por vectores a los seres humanos y animales. Es causada por parásitos protozoarios del género Leishmania. Los caninos son susceptibles de adquirir la forma visceral y la forma cutánea (L. braziliensis, $L$. panamensis) y son los principales reservorios de Leishmania infantum, el agente causal de la forma visceral en humanos. La leishmaniosis visceral canina es una infección crónica que puede llevar a los animales a la muerte. Es endémica en varios países de Latinoamérica, el Mediterráneo y África. Se constituye como un grave problema tanto de salud pública como para el médico veterinario. El pronóstico en los animales es peor que en los humanos, debido a las dificultades y a la ineficacia en el tratamiento, lo que deriva en la decisión de sacrificar los animales positivos, sobre todo en lugares donde es endémica, hay un alto número de casos humanos y poca disponibilidad de terapias alternativas (1).

Esta enfermedad es una de las principales zoonosis reconocidas a nivel mundial, con potencial fatal para seres humanos y animales y los caninos son el principal reservorio o fuente de infección para los humanos. En la clínica se manifiesta con un sin número de síntomas y grados de severidad. Actualmente no existe un consenso unificado acerca del manejo de la enfermedad (2).

La enfermedad se transmite a los mamíferos a través de la picadura de flebótomos hembra infectados de forma natural. La distribución geográfica de la leishmaniosis está limitada a la distribución de los vectores del género Lutzomyia, los cuales son responsables de la transmisión de la enfermedad en América y los del género Phlebotomus en el viejo mundo (Europa, Asia y África) (3). Existen tres formas principales de presentación: Cutánea (más común), Mucocutánea y Visceral (considerada la más grave y también conocida como kala-azar) (4). En Colombia, según el Instituto Nacional de Salud (INS), se ha venido observando un incremento en el número de casos de Leishmaniosis cutánea, enfermedad que es considerada endémica en casi todo el territorio nacional, exceptuando San Andrés Islas, Bogotá y Atlántico, y se cree que hay más de 10 millones de personas en riesgo de contraerla, considerándose como focos que coinciden con la distribución del vector los departamentos de Tolima, Huila, Cundinamarca, Bolívar, Córdoba, Sucre, Santander y Norte de Santander, entre otros (5).

Los protagonistas de la violencia armada en el país se encuentran ampliamente expuestos a la picadura de Lutzomyia, así como los militares que van a combatir en zonas rojas o territorios poco habitables. De igual manera, la presentación de la 
zones or uninhabited territories are also at high risk of exposure. Likewise, the type of disease depends on two key factors: the presence of the vector and the infected reservoirs (6). According to this statement, the members of the armed forces have all the risks factors, which are: movement through areas where the vectors are present and contact with main reservoirs, among them the most important, the dogs. Within the different reservoirs to the dog we can find: wild rodents, sloths, armadillos, forest mammals and some arboreal mammals, such as the opossum (Didelphis marsupialis). The most important are man, the dog and the opossum (7), although this depends on the parasite species involved and the natural source of the infection. In summary, in Colombia there are 3 epidemiological transmission cycles: jungle cycle, where men enter into jungle areas and are bitten by the vector (in the case of soldiers, armed conflict players, local pheasants, illegal crop sowers, deforesters, kidnapped, oil workers, etc.), a rural domestic cycle and an urban cycle. In these two cycles, the vector enters homes and can affect the entire family, especially children when the byte habitat starts in the late afternoon or night hours, like in the case of Lu. gomezi.

\section{The parasite and the life cycle of the disease}

There are two types of stages of causative parasites of Leishmaniasis: promastigotes, which present a flagellum that allows them to move inside the vector of the alimentary tract and the amastigote, which are intracellular and they multiply in the macrophages. The parasite completes the cycle in two hosts, the vector and the reservoir. Promastigotes mature in the alimentary tract of the vector and are then transmitted in their infective form to the reservoirs. These promastigotes are engulfed by macrophages and are transformed into amastigotes, later multiplying into other macrophages and migrating to various organs. This is how the disease can be transmitted in various ways (the canines being reservoirs): blood transfusions, vertical transmission and venereal transmission (2). It follows that those canines with high genetic value or high value for their training and performance in different activities (explosivesniffing, drug-sniffing, breeders, other) and that are suspects or are positive, its reproduction must be stopped or avoided, and should not be used as blood donors because they may transmit the disease.

Nowadays, bytes of infected canines and the transmission through ticks and fleas are not considered as transmission mechanisms (2).

In a domestic environment, not only can canines be infected by parasites; there are other types of enfermedad depende básicamente de dos factores claves: la presencia del vector y los reservorios infectados (6). Según este postulado, los miembros de las fuerzas armadas tienen todos los factores de riesgo presentes, los cuales son: circulación por zonas donde se encuentran los vectores y el contacto con los principales reservorios, entre ellos el más importante, el perro. Dentro de los reservorios diferentes al perro podemos encontrar: roedores silvestres, perezosos, armadillos, mamíferos de bosque y algunos arbóreos, como la zarigüeya (Didelphis marsupialis). Los más importantes son el hombre, el perro y la zarigüeya (7), aunque esto depende de la especie involucrada del parásito y del foco natural de infección. En resumen, en Colombia, se presentan 3 ciclos epidemiológicos de transmisión: el selvático, en el cual el hombre ingresa a zonas selváticas donde es picado por el vector (el caso de soldados, alzados en armas, campesinos, sembradores de cultivos ilícitos, deforestadores, secuestrados, trabajadores de oleoductos, etc), un ciclo domestico rural y un ciclo urbano. En estos dos ciclos el vector ingresa a las casas y puede afectar a toda la familia, especialmente a los niños cuando el hábito de picadura comienza en horas de la tarde-noche, como el caso de Lu. gomezi.

\section{El parásito y el ciclo de vida de la enfermedad}

Los parásitos causantes de la Leishmaniosis tienen dos tipos de estadios: los promastigotes, quienes presentan un flagelo que les permite movilizarse en el intestino del vector, y los amastigotes, los cuales son intracelulares y se multiplican en los macrófagos. El parásito completa el ciclo en dos huéspedes, el vector y los reservorios. Los promastigotes maduran en el intestino del vector y luego son transmitidos en su forma infectiva a los reservorios, estos promastigotes son fagocitados por macrófagos y se transforman en amastigotes, multiplicándose luego en otros macrófagos y migrando hacia diversos órganos. Es así como la enfermedad se puede transmitir de diversas maneras (siendo reservorios los caninos): transfusiones sanguíneas, transmisión vertical y transmisión venérea (2). De lo anterior se deriva que aquellos caninos de alto valor genético o de alto valor por su entrenamiento y rendimiento en diversas labores (antiexplosivos, antinarcóticos, jefe de raza, otros) y que sean sospechosos o sean positivos, debe evitarse su reproducción o evitar utilizarlos como donadores de sangre, ya que pueden transmitir la enfermedad.

Hoy en día, no son considerados mecanismos de transmisión las mordeduras de caninos infectados y la transmisión a través de garrapatas o pulgas (2).

En el ámbito doméstico, no solo los caninos pueden 
species that serve as food source for the vector, such as felines and equines as well as bovines and domestic birds. Other types of unconventional pets like rabbits, gerbils, hamsters, mice and lab rats are also susceptible of acquiring the disease (8). Leishmaniasis is not a significant disease in bovines. Some cases have been reported in equines as well as in sheep, goats and cattle in Africa, and one case in pork was reported in South America. Likewise, some antibodies have been reported in donkeys, cows, goats and pigs. Infected pigs and sheep have not developed the disease in experiments. 10 This does not mean that all types of species develop the disease or have some epidemiological importance in the transmission cycle. It means that they can be a food source for the vector. Epidemiologically and clinically, the importance lies in the canine as main reservoir.

\section{Pathogenesis of the disease in the dog and the cat}

After the byte of the phlebotominae, a complex immune reaction is triggered in the host. In order to repair the injured tissue, the proinflammatory cells such as nutrophile, macrophages and "killer cells" (NK) initially migrate. These cells are in charge of gobbling the majority of promastigotes in order to destroy them (9). Within the macrophages, which also gobble neutrophiles, a series of enzymatic reactions are triggered to destroy the parasite. Nevertheless, this is not always accomplished and, on the contrary, the amastigotes begin to multiply and break the membrane of the macrophage, scattering themselves through the blood and lymphatic vessels to the main organs and tissues. From that moment, a severe inflammatory chain is initiated because in the closest regional lymphatic gland, dentridic cells present parasite antigens to the Lymphocytes T "helpers (Th)" and to the cytotoxic Lymphocytes T (LTC), who will proliferate themselves and will differentiate in LTh1 producers of the Interferon (IFN-g) gamma or the LTh2 producers of cytokines (IL-4, IL-5, IL-10, IL-13). These Th2 Lymphocytes promote the infection of more macrophages through the interaction of immunoglobulins and block the activation mechanisms of the macrophages. This makes the intracellular parasite to multiply. Th1 lymphocytes predominate in the initial stages when the immune response is cellular, when there are low antibody titers and it seems that the infection is controlled (self-limiting). In this stage, the dog is apparently healthy. Th2, predominate in the severe stage of the disease. There are high antibodies; the cellular immunity drops and there is a high population of parasites in the entire organism. Also, there is non-specific activation of all the humoral system, specially the Immunoglobulin G (IgG). In this reaction the aqueous humor may even be verse infectados por el parásito, existen otras especies tales como felinos y equinos, y como fuente de alimentación para el vector pueden encontrarse bovinos y aves domésticas. Otro tipo de mascotas no convencionales como conejos, gerbos, hámsters, ratas y ratones de laboratorio, son susceptibles de adquirir la enfermedad (8). La leishmaniosis no es una enfermedad significativa en los bovinos, en los equinos se han reportado casos, igual en ovinos, cabras y ganado en África además de un caso de un porcino en Sudamérica. De igual manera se han reportado anticuerpos en burros, vacas y cabras y cerdos. Cerdos y ovejas infectados de forma experimental no han desarrollado la enfermedad. (10). Lo anterior no significa que todas estas especies desarrollen la enfermedad o tengan alguna importancia epidemiológica en el ciclo de transmisión, solo que pueden ser fuente de alimentación para el vector. Epidemiológicamente y clínicamente la importancia radica en el canino como principal reservorio.

\section{Patogenia de la enfermedad en el perro y el gato}

Posterior a la picadura del flebótomo, se desencadena una respuesta inmunológica compleja en el hospedero. Con el fin de reparar el tejido lesionado, inicialmente migran células proinflamatorias como neutrófilos, macrófagos y "células asesinas" (NK), quienes se encargan de fagocitar la mayoría de promastigotes para destruirlos (9). Dentro de los macrófagos, que también fagocitan neutrófilos, se generan una serie de reacciones enzimáticas con el fin de destruir el parásito, sin embargo, esto no siempre se logra y por el contrario, los amastigotes comienzan a multiplicarse y rompen la membrana del macrófago diseminándose por vía sanguínea y linfática a los principales órganos y tejidos. A partir de ese momento, inicia una cadena inflamatoria severa, ya que en el ganglio linfático regional más cercano, las células dendríticas presentan los antígenos del parásito a los Linfocitos T "ayudadores (Th)" y a los Linfocitos T citotóxicos (LTC), quienes van a proliferar y a diferenciarse en LTh1 productores de Interferón gamma (IFN-g) o a LTh2 productores de citoquinas (IL-4, IL-5, IL-10, IL-13). Estos Linfocitos Th2 promueven la infección de más macrófagos a través de la interacción de inmunoglobulinas y bloquean los mecanismos de activación de los macrófagos, lo cual hace que el parásito intracelular se multiplique. Los linfocitos Th1, predominan en los estadios iniciales, cuando la respuesta inmune es celular, hay títulos bajos de anticuerpos y al parecer la infección está controlada (autolimitante). En este estadio el perro se encuentra aparentemente sano. Los Th2, predominan en el estadio severo de la enfermedad, hay anticuerpos elevados, decae la inmunidad celular y hay una alta población de 
found in dogs with a specific anti-Leishmania IgG, confirmed through ELISA. This triggers a migration of complex Antigen-Antibodies that in some cases can cause uveitis.

Cats are more resistant than dogs probably because they have more cellular immunity, which acts at first contact with promastigotes. This is proven by most of the reported cases where more than $70 \%$ of the positive felines had their immune system compromised with pathologies such as: malignancy, retrovirus, etc. As with canines, cutaneous signs dominate. Even though there are no more than 40 to 50 cases reported in felines, and felines are considered an accidental host, it is important to consider at the clinic this species as a possible frequent host of the parasite, mainly when they come from endemic zones (11).

In the dog two patterns of immune presentation are described: patients were the cellular immune response dominates and there is a low production of antibodies (these patients are associated with the resolution of symptoms but they continue to be positive); and those patients where there is a high production of antibodies (IgG and IgE). These patients develop the disease progressively and show a variety of clinical symptomatology (12). A relevant aspect of the immune response in the disease is the formation of immune complexes in different organs of the animal, which is reflected in different clinical complications (interstitial pneumonia, uveitis, interstitial nephritis), which makes the treatment at the clinic more difficult.

\section{Clinical presentation of the canine Leishmaniosis}

The clinical signs as well as the symptomatology are very variable and they depend on the strain that infects the dog; if cutaneous ( $L$. panamensis, $L$. braziliensis) or if visceral ( $L$. infantum); the prognosis and the clinical presentation also depends on this. This disease affects animals of all breeds, ages and sex. Some dogs or some breeds seem to be more resistant to the development of the disease and only show a localized nodular reaction at the site of the byte. In other countries, only a percentage (10\%) develops a clinical form. When developed, animals may present symptoms such as: local or generalized lymphadenopathy, diverse cutaneous injuries such as ulcers (in some cases similar to bedsores) (Figure 1), alopecia in some areas, splenomegaly (Figure 2), epistaxis, progressive wasting (even when the patient has not lost appetite or the food is of good quality), eye injury which result in most cases from reactions to hypersensitivity type IV (uveitis, conjunctivitis, keratoconjunctivitis, blepharitis) (Figure 3), renal insufficiency, diarrhea, hematuria, limps and parásitos en todo el organismo. Asimismo, hay una activación inespecífica de todo el sistema humoral, especialmente de Inmunoglobulina G ( $\mathrm{ggG}$ ), reacción en la cual se puede inclusive encontrar en el humor acuoso de los perros una IgG específica anti-Leishmania, confirmada a través de ELISA, lo que desencadena una migración de complejos Antígeno-Anticuerpo, que en algunos casos puede producir uveítis.

Los gatos son más resistentes que los perros probablemente a que tienen una mejor inmunidad celular, la que actúa en el primer contacto con los promastigotes. Esto lo demuestran la mayoría de casos reportados, donde más del $70 \%$ de los felinos positivos tenían el sistema inmune comprometido, con patologías tales como: neoplasias, retrovirus, etc. Al igual que en los caninos predominan los signos cutáneos. Aunque existen no más de 40 a 50 casos reportados en felinos, y éste se consideraba un hospedador accidental, es importante considerar en la clínica a esta especie como un posible huésped frecuente del parásito sobre todo cuando provienen de zonas endémicas (11).

En el perro están descritos dos patrones de presentación inmune: pacientes en donde predomina la respuesta inmune celular y hay baja producción de anticuerpos (estos pacientes se asocian con resolución de síntomas pero siguen siendo positivos) y aquellos pacientes donde hay una alta producción de anticuerpos (IgG e IgE), estos pacientes desarrollan la enfermedad de manera progresiva y muestran una variada sintomatología clínica (12). Un aspecto relevante de la respuesta inmune en la enfermedad es la formación de complejos inmunes en diferentes órganos del animal, lo cual se ve reflejado en diferentes complicaciones clínicas (neumonía intersticial, uveítis, nefritis intersticial), lo cual hace más difícil aún el tratamiento en la clínica.

\section{Presentación clínica de la Leishmaniosis canina}

Los signos clínicos son muy variables, al igual que la sintomatología, y depende de la cepa con la que el perro se infecte; si es cutánea ( $L$. panamensis, $L$. braziliensis) o visceral ( $L$. infantum); de esto también depende el pronóstico y la presentación clínica. Esta enfermedad afecta a animales de todas las razas, edades y sexos. Algunos perros o algunas razas parecen ser resistentes al desarrollo de la enfermedad y sólo muestran una reacción nodular localizada en el lugar de la picadura del flebótomo. En otros países, solo un porcentaje (10\%) desarrollan la forma clínica. Cuando ésta se desarrolla los animales pueden presentar síntomas tales como: linfadenopatía local o generalizada, diversas lesiones cutáneas como 


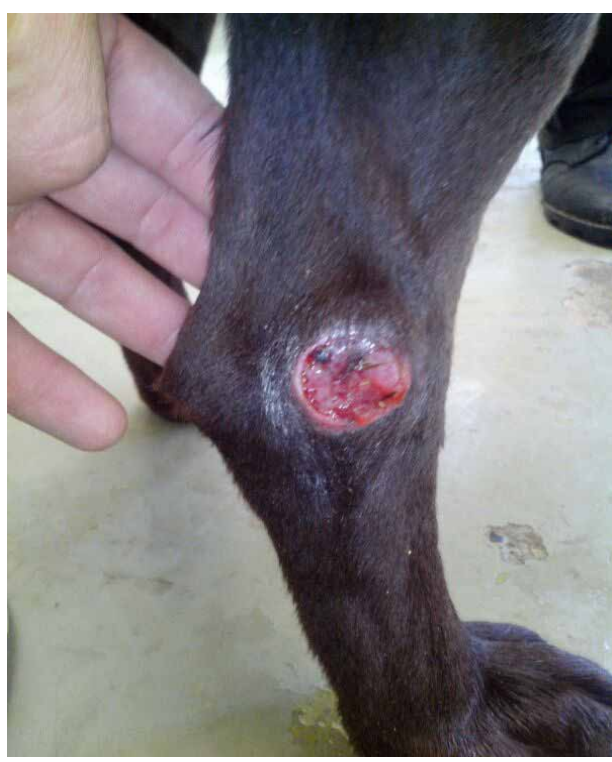

Figure 1. Ulcer in hind limb of patient with suspicion of visceral leishmaniasis.

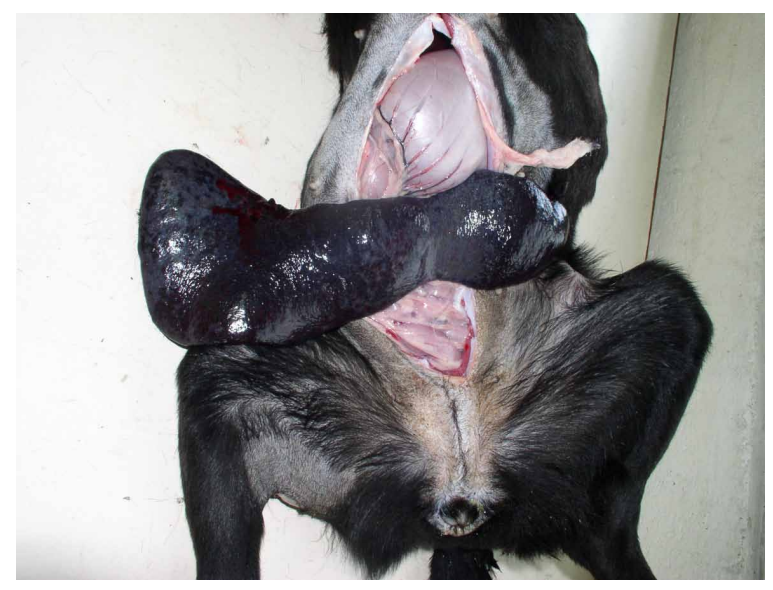

Figure 2. Splenomegaly of canine with visceral leishmaniasis.

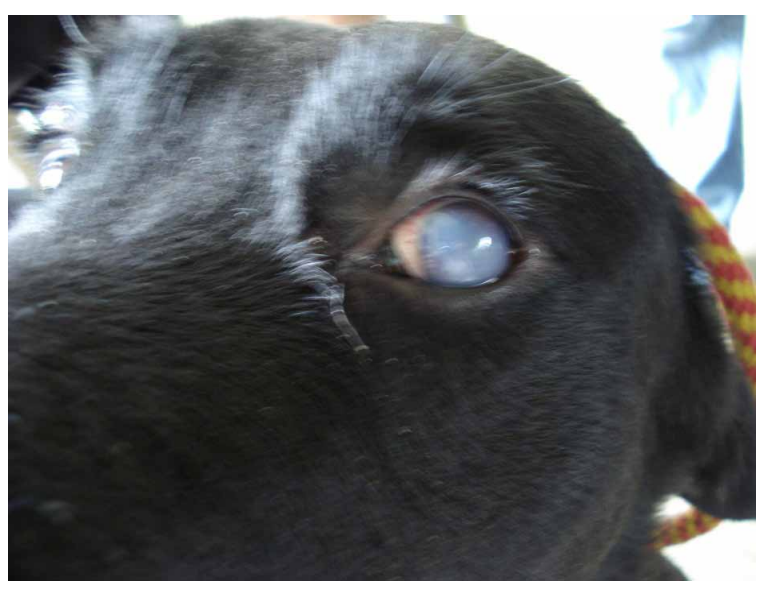

Figure 3. Ocular manifestations in canine with suspicion of visceral leishmaniasis. úlceras (en algunos casos parecidas a úlceras por decúbito) (Figura 1), alopecia en algunas zonas, esplenomegalia (Figura 2), epistaxis, emaciación progresiva (aun cuando el paciente no ha perdido el apetito o el alimento es de buena calidad), lesiones oculares resultado en la mayoría de las veces por reacciones de hipersensibilidad tipo IV (uveítis, conjuntivitis, queraconjuntivitis, blefaritis) (Figura 3 ), insuficiencia renal, diarrea, hematuria, cojeras y onicogrifosis (crecimiento exagerado y anormal de las uñas), temperatura normal en unos casos y fiebre en otros, atrofia muscular, diferentes tipos de dermatitis (exfoliativa, nodular, pustular). De igual manera se pueden presentar lesiones articulares como poliartritis. $(13,14)$. En algunos caninos machos, se pueden observar úlceras a nivel escrotal (Figura 4).

Las afecciones renales ocurren en casi todos los caninos infectados con el parásito. La enfermedad renal se puede presentar como glomerulonefritis (asociada a depósito de complejos inmunes), nefritis intersticial, síndrome nefrótico y progresar a insuficiencia renal crónica. En el hemograma pueden aparecer anormalidades en las plaquetas y anemia. En algunos casos la causa de la muerte puede ser la pérdida de sangre incontrolable, además de la posible eritrolísis inmunomediada (14). Es posible que algunos pacientes desarrollen otras complicaciones tales como la coagulación intravascular diseminada, asociado probablemente a las hemorragias, al consumo de plaquetas y factores de coagulación. Esta complicación no ocurre de manera primaria, suele venir precedida de otros trastornos o condiciones clínicas como sepsis y hemólisis, las cuales coinciden con pacientes infectados por el parásito (15).

La glomeruonefritis se desarrolla debido al depósito de inmunocomplejos en las paredes de los capilares glomerulares. Estos complejos inmunes causan proliferación de células glomerulares y engrosamiento de las paredes capilares, lo que morfológicamente se denomina hialinización y esclerosis glomerular. Estas lesiones irreversibles dañan la nefrona y a medida que avanza la enfermedad, se disminuye la filtración glomerular, lo que resulta en insuficiencia renal y azotemia. De todos los mecanismos que cursan con glomerulopatías progresivas, las inmunomediadas son las más importantes, aunque en los casos de leishmaniasis aún no está totalmente definida su fisiopatología (16). Los animales infectados por el parásito muestran una serie de manifestaciones clínicas compatibles con diversas enfermedades lo cual hace aún más difícil que el Médico Veterinario sospeche en un primer momento de una infección por Leishmania. Es por esto que los profesionales de 
onychogryphosis (excessive and abnormal nail growth), normal temperature in some cases and fever in others, muscular atrophy, different types of dermatitis (exfoliative, nodular, pustular). Joint injuries such as polyarthritis can also be present. $(13,14)$. In some male canines, ulcers at the scrotal level can be observed (Figure 4).

Kidney failures occur in almost all canines infected with the parasite. Kidney failure can manifest itself as glomerulonephritis (associated with the deposit of immune complexes), interstitial nephritis, nephritic syndrome and can progress to chronic kidney failure. Abnormalities in the plaques and anemia can appear in the blood count. In some cases, the cause of death can be uncontrollable loss of blood as well as possible immune-mediated erythrolysis (14). Its possible that some patients develop other complications such as disseminated intravascular coagulation probably associated to the hemorrhages, platelet consumption and coagulation factors. This complication is not primary. The complication is usually preceded by other disorders or clinical conditions such as sepsis and hemolysis, which coincides in patients infected by the parasite (15).

Glomerulonephritis is developed due to the deposit of immune complexes in the glomerular capillary walls. These immune complexes cause the proliferation of glomerular cells and enlargement of the capillary walls, which is morphologically called hyalinization and glomerular sclerosis. These irreversible injuries cause damage to the nephrone and as the disease progresses, the glomerular filtration decreases, resulting in kidney failure and azotemia. Of all the mechanisms that cause progressive glomerulopathies, the immune-mediated are the most important; although in some cases of leishmaniasis, the pathophysiology has not been completely defined (16).

Animals infected with the parasite show a series of clinical manifestations compatible with various diseases that make it more difficult for the Veterinary Doctor to suspect infection from Leishmania in a first instance. This is why the professionals at the veterinary clinic must consider the disease within the possible differential diagnoses when a patient from endemic areas of less than 2,000 meters above sea level arrives with the injuries described above.

\section{The diagnosis of canine visceral Leishmaniasis}

When there is a suspicion that a canine has leishmaniasis, the basic tests are blood count, a biochemical hepatic or renal profile as well as

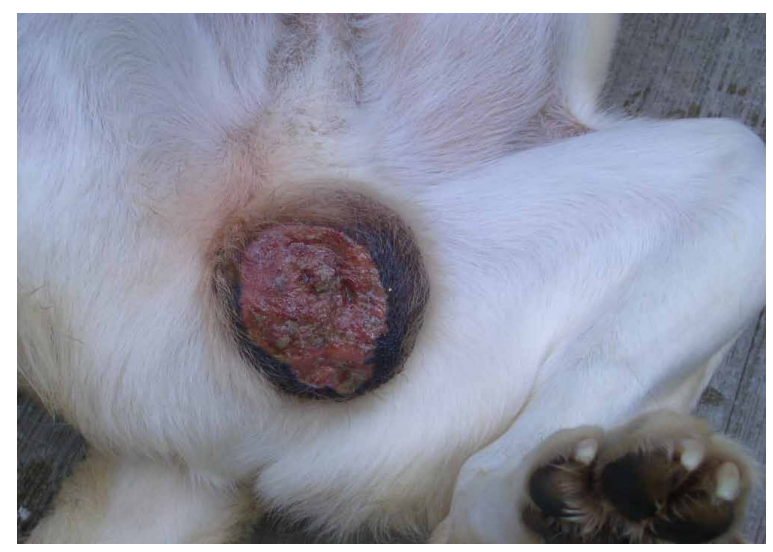

Figure 4. Ulcer at the scrotal level of patient with suspicion of cutaneous leishmaniasis.

la clínica veterinaria deben tener en cuenta esta enfermedad dentro de los posibles diagnósticos diferenciales cuando les llegue un paciente proveniente de zonas endémicas, de menos de 2.200 metros sobre el nivel del mar, con lesiones como las descritas anteriormente.

\section{El diagnóstico de la Leishmaniosis visceral canina}

Cuando se sospecha de un canino con leishmaniosis, los exámenes básicos como un hemograma, un perfil bioquímico hepático o renal así como un urianálisis son de gran importancia para evaluar la condición del paciente y si ya existe algún grado de insuficiencia renal $(17,18)$. En el hemograma de un paciente con Leishmania se puede observar anemia normocítica normocrómica no regenerativa y leucopenia en las formas graves; en los perfiles bioquímicos se puede evidenciar aumento de ALT y AST, en algunos casos, y con mayor frecuencia incremento de urea y creatinina. En el urianálisis se puede hallar proteinuria con presencia de cilindros en el sedimento, indicativo de glomerulonefritis $(17,18)$.

Con el fin de conseguir muestras para observar el protozoo, pueden obtenerse punciones 0 impresiones de médula ósea (fundamentalmente en la costilla, el fémur y la cresta ilíaca, unión costo-condral o esternón), de ganglio linfático poplíteo (o cualquier otro ganglio que presente linfadenomegalia) o de la porción subcutánea de las lesiones o úlceras si corresponde a un caso sospechosos de presentar la forma cutánea. Se puede realizar una tinción de Giemsa. La presencia de un sólo amastigote en el interior de los macrófagos se considera diagnóstica de infección, por lo que esta prueba es muy rápida para conocer si el paciente es positivo. También se puede realizar la detección 
a urinalysis, which are of great importance to evaluate the condition of the patient if there is already some degree of kidney failure $(17,18)$. In the blood count of a patient with Leishmania, normocytic normochromic non regenerative anemia and leukopenia in severe forms can be observed; in the biochemical profiles an increase in ALT and AST can be observed, and in some cases, and with more frequency, an increase in the urea and creatinine levels. In the urinalysis, proteinuria with presence of casts in the sediment can be found, which is indicative of glomerulonephritis $(17,18)$.

In order to obtain samples to observe the protozoa, punctures or impressions of the bone marrow (mainly the rib, the femur and the iliac crest, the costochondral joint or the sternum), poplyteal lymph nodes (or any other node that presents lymphadenomegaly) or of a subcutaneous portion of the injuries or the ulcers if they correspond to a suspicious case of cutaneous form, can be collected. A Giemsa stain can be performed. The presence of only one amastigote inside the macrophages is considered a diagnosis of infection. Therefore, the test is very fast to know if the patient is positive. The detection of circulating anti-Leishmania antibodies can be performed (mainly IgG and specially IgG1 and IgG2) by means of serology. In dogs with leishmaniasis, the humoral response is very high, which causes a large production of IgGs. There are other methods for diagnosis that vary in sensibility and specificity such as immunohistochemistry, histopathology of affected tissue, PCR and ELISA. In general, PCR and other tests are used for the diagnosis and in order to identify the Leishmania strain that affects the dog, for the prognosis and to obtain epidemiological data from the zone where the patient comes from (19).

Also, there are culture media (NNN, amended Schneider's, Senekjie's two-phase media, media enriched with fetal serum or cell cultures of insects). These culture media, although specific, cannot be used for fast diagnosis and are used only for research to extend and determine the leishmania stain that was found. The sensitivity of culture media is approximately $68 \%$, although it depends on if the stain is the cause of the visceral or cutaneous form $(19,20)$.

Cytology (lymph nodes, bone marrow) and staining are also fast and effective tools to identify positive dogs in cases where the patient shows evident clinical signs and signs compatible with the disease. Nevertheless, this tools is not efficient in dogs that live in endemic areas because many times the signs are diffuse and de anticuerpos anti-Leishmania circulantes (principalmente IgG y especialmente IgG1 e IgG2) por medio de serología. En perros con leishmaniosis, la respuesta humoral es muy alta, lo que genera una gran producción de IgGs. Existen otros métodos diagnósticos que varían en sensibilidad y especificidad, la inmunohistoquímica, histopatología de tejidos afectados, PCR y ELISA. En general la PCR y otras pruebas se determinan para el diagnóstico y con el fin de identificar la cepa de Leishmania que afecta al perro, para el caso del pronóstico y de querer obtener datos epidemiológicos de la zona de donde proviene el paciente (19).

De igual manera existen medios de cultivo (NNN, Schneider's modificado, Senekjie's medio bifásico, medios enriquecidos con suero fetal o cultivos celulares de insectos). Estos medios de cultivo, aunque son específicos, no sirven para un diagnóstico rápido y se utilizan solamente para investigación, ampliar y determinar la cepa de leishmania encontrada. La sensibilidad de los medios de cultivo está alrededor del 68\%, aunque depende si la cepa es causante de la forma visceral o cutánea $(19,20)$.

La citología (ganglios linfáticos, médula ósea) y tinción también es una herramienta rápida y eficaz para identificar los perros positivos, en aquellos casos en los cuales el paciente muestra signos clínicos evidentes y compatibles con la enfermedad. Sin embargo, esta herramienta no es eficaz en perros que viven en áreas endémicas ya que muchas veces los signos son difusos y no específicos. Es muy importante la interpretación de los signos para acercarse al estado real del paciente. Se proponen cuatro posibles interpretaciones de los resultados de las pruebas diagnósticas así:

Se define a un paciente con leishmaniosis activa cuando tiene tejidos dañados y la citología es positiva.

Si la citología es negativa, la serología es la herramienta a elegir para confirmar los títulos de anticuerpos.

En el caso de presentar lesiones cutáneas se debe realizar una biopsia cutánea. Aunque existan signos y la citología salga negativa, se recomienda inmunohistoquímica y PCR de tejido cutáneo.

Sin lesiones cutáneas pero con síntomas sistémicos compatibles con leishmaniosis, se recomienda realizar PCR para detectar el ADN del parásito, los tejidos podrían ser médula ósea o ganglios linfáticos. 
are not specific. The interpretation of the signs is very important to get closer to the real state of the patient. Four possible interpretations of the results of the diagnostic tests are proposed as follows:

A patient with active leishmaniasis is defined when both damaged tissues and the cytology are positive.

If the cytology is negative, the serology is the tool to choose to confirm the antibody titers.

In the event that the patient has cutaneous injuries, a cutaneous biopsy must be preformed. Even if there are signs and the cytology is negative, immunohistochemistry and PCR of the cutaneous tissue are recommended.

Without cutaneous injuries but with compatible systemic symptoms with leishmaniasis, a PCR to detect the DNA of the parasite is recommended. The tissues could be bone marrow or lymph nodes.

Nevertheless, those suspicious patients that present low titers, must be monitored because the infection can be reactivated. Titers of low antibodies indicate prior contact with the parasite (21).

\section{Treatment for canine Leishmaniasis}

To initiate the treatment against Leishmaniasis, there must be in first place a confirmed diagnosis, since some of the drugs used for this therapy are highly nephrotoxic. The objectives of the treatment must be focused on the reduction of the parasite load, in the restoration of the efficiency of the immunologic system, in treating the damaged tissue, providing a clinical improvement and thus, improving the quality of life of the patient, and reducing the probability of transmission of the parasite (22).

The most common drugs used for the treatment of canine Leishmaniasis are meglumine antimoniate (Gucantime ${ }^{\circledR}$ ), Allopurinol, Amphotericin B, Miltefosine or the combination of meglumine antinomate and allopurinol. Although today other drugs have also been used such as Enrofloxacin, Domperidone, Pentamidine and the combination of Spiramicyn-Metronidazole, until now and by unanimity of several groups of experts in canine leishmaniasis, the combination of meglumine antinomate (Glucantime ${ }^{\circledR}$, dosage of 75$100 \mathrm{mg} / \mathrm{kg} /$ day via SC) + Allopurinol $(10-20 \mathrm{mg} / \mathrm{kg} /$ day by mouth-during 6 months to 1 year) has been established as the most used and efficient protocol and is the treatment of choice for this disease $(22,23)$.
Sin embargo, aquellos pacientes sospechosos, que presentan títulos bajos, deben ser monitoreados ya que la infección se puede reactivar. Títulos de anticuerpos bajos indican un contacto previo con el parásito (21).

\section{Tratamiento de la Leishmaniosis canina}

Para instaurar el tratamiento contra Leishmaniosis, en primer lugar se debe tener un diagnóstico confirmado, ya que algunos de los fármacos utilizados para esta terapéutica son altamente nefrotóxicos. Los objetivos del tratamiento deben ir enfocados a la reducción de la carga parasitaria, restaurar la eficiencia del sistema inmunológico, tratar el daño tisular, proveer mejoría clínica y por ende una mejor calidad de vida al paciente, disminuyendo la probabilidad de transmisión del parásito (22).

Los fármacos más utilizados para el tratamiento de Leishmaniosis canina son el Antimoniato de meglumina (Glucantime ${ }^{\circledR}$ ), Alopurinol, Anfotericina B, Miltefosina, o la combinación de Antimoniato de meglumina y Alopurinol. Aunque hoy por hoy también se ha implementado el uso de otros fármacos como Enrofloxacina, Domperidona, Pentamidina y la combinación EspiramicinaMetronidazol, hasta ahora y por unanimidad de varios grupos de expertos en leishmaniosis canina, la combinación Antimoniato de meglumina (Glucantime ${ }^{\circledR}$, a dosis de $75-100 \mathrm{mg} / \mathrm{kg} /$ día vía $\mathrm{SC}$ ) + Alopurinol (10-20 mg/kg/día vía oral-por 6 meses a 1 año) se establece como el protocolo más empleado, eficaz y de elección en el tratamiento de esta enfermedad $(22,23)$.

Es importante resaltar que en América, no se recomienda el tratamiento de caninos sospechosos o confirmados de leishmaniosis visceral debido a que: no se curan así clínicamente se vea mejoría de los signos clínicos, las recaídas son constantes, la cepa de Leishmania puede generar resistencia y el tratamiento no está disponible comercialmente. De igual manera es importante saber que existen evidencias que demuestran que pueden existir perros infectados y asintomáticos que pueden actuar como reservorios, con capacidad de infectar a los vectores, de ahí que la recomendación sea el sacrificio. Sin embargo, se exponen aquí los tratamientos disponibles según diversas referencias, lo cual no indica que esto sea lo indicado, por eso es importante el criterio del médico veterinario y el impacto en salud pública que pueda tener el canino sospechoso.

Los antimoniales pentavalentes menos tóxicos, operan como pro fármacos que, normalmente son reducidos hasta la forma más tóxica y eficaz (la 
Its important to highlight that in America, treatment of suspicious or confirmed canines with visceral leishmaniasis is not recommended because: they will not be cured even though they clinically show an improvement in the clinical signs, relapses are constant, the stain of Leishmania may become resistant and the treatment is not commercially available. Also, its important to know that there is evidence that shows that infected and asymptomatic dogs can exist that can act as reservoirs, with the capacity to infect the vectors. For such reason, slaughtering a dog is recommended. Nevertheless, the available treatments are described herein according to various references, but this does not mean that this is the right approach. This is why the criteria of the veterinary doctor and the impact to public health that the suspicious canine could have is important.

The least toxic pentavalent antimonias operate as prodrugs that normally are reduced to its most toxic and efficient form (the trivalent form), because they destroy the amastigotes in the phagolysosome of the macrophages. Recently, an enzyme capable of reducing the antimonials from pentavalent to trivalent reductase AsV was discovered. The presence of this enzyme in promastigotes, increases its sensitivity towards drugs. The trivalent form demonstrated a greater speed of distribution than the pentavalente form. This is due to its greater electrochemical reaction capacity. Trivalent antimonial has expressed affinity with the erythrocytes in which it is deposited for 24 to 48 hours and in macrophages it can be accumulated for at least three days, reducing the freely available antimony for excretion. Reports have been known that pentavalent antimonial has a fast distribution and slow elimination, while in trivalent antimonia, these characteristics increased and decreased very slowly (24).

Currently, promastigotes (depending on the stain of Leishmania) can offer resistance to the antimonial pentavalentes, which generates low reliability in the treatment. In some countries, this resistance can exceed $40 \%$ of the cases. One of the alternatives in the treatment is miltefosine, which has a prolonged average life expectancy, which at medium or long term could generate resistance. Perhaps the best option is a combination treatment (similar to the management of patients with malaria, tuberculosis or leprosy), in order to strengthen the effects of the medications, to include two or three action mechanisms, reduce the dosage to those which are more toxic, limit resistance and probably reduce costs. Miltefosine increases the activity of amphotericin $B$ and meglumine antimoniate (25). First-line drugs are: meglumine antimoniate, allopurinol, a combination of these two and finally the anphotericin B. Second-line forma trivalente), ya que destruyen los amastigotes en los fagolisosomas de los macrófagos. Hace poco, se descubrió una enzima capaz de reducir los antimoniales de pentavalente a trivalente, la reductasa de AsV. La presencia de esta enzima en los promastigotes, aumenta su sensibilidad hacia los fármacos. La forma trivalente demostró una mayor velocidad de distribución que la forma pentavalente, esto es por su mayor capacidad de reacción electroquímica. El antimonial trivalente ha expresado afinidad por los eritrocitos, en los cuales se deposita por 24 a 48 horas, y en los macrófagos se pueden acumular por al menos tres días, acortando el antimonio libre disponible para la excreción. Se ha reportado que el antimonial pentavalente tiene una rápida distribución y una lenta eliminación, mientras que con el antimonio trivalente estas características subieron y bajaron muy lentamente (24).

Actualmente los promastigotes (dependiendo de la cepa de Leishmania) pueden presentar resistencia a los antimoniales pentavalentes, lo que genera una baja confiabilidad en el tratamiento. En algunos países esta resistencia puede superar el $40 \%$ de los casos. Una de las alternativas en el tratamiento es la miltefosina, la cual tiene una vida media prolongada, lo cual también a mediano - largo plazo podría generar resistencia. Tal vez la mejor opción es un tratamiento combinado (similar al manejo de pacientes con malaria, tuberculosis o lepra), con el propósito de potenciar los efectos de los medicamentos, abarcar dos o tres mecanismos de acción, reducir la dosis de los que son más tóxicos, limitar la resistencia, y probablemente reducir costos. La miltefosina aumenta la actividad de anfotericina B y el antimoniato de meglumina (25). Los medicamentos de primera línea son: el antimoniato de meglumina, alopurinol, la combinación de los dos anteriores y por último la anfotericina $B$. Los de segunda línea son la aminosidina, pentamidina, metronidazol y enrofloxacina, metronidazol y espiramicina, miltefosina y ketoconazol (19).

El tratamiento de las úlceras de la piel con inyecciones locales de antimonio pentavalente podría convertirse en un enfoque razonable para disminuir el riesgo de infección humana en el entorno peri-domésticos, sin necesidad de sacrificar los perros infectados (en aquellos países donde está disponible el tratamiento). Estas lesiones sanan en un período de 2 a 6 semanas (26). Sin embargo, deben realizarse estudios que evidencien que este tratamiento disminuye realmente el riesgo de transmisión post-tratamiento.

Otro de los posibles tratamientos es la Miltefosina. El mecanismo de acción de la miltefosina como fármaco frente a la leishmaniosis se basa en su 
drugs are aminosidine, pentamidine, metronidazole and enrofloxalin, metronidazole and spiramycin, miltefosine and ketoconazole (19).

Treatment of skin ulcers with local pentavalent antimony injections could become a reasonable approach to reduce the risk of human infection in the peridomestic environment, without the need of slaughtering the infected dogs (in those countries where the treatment is available). These injuries heal within a period of 2 to 6 weeks (26). Nevertheless, studies must be conducted to prove that this treatment really reduces the posttreatment risk of transmission.

Another possible treatment is Miltefosine. The mechanism of action of miltefosine as a drug to treat leishmaniasis is based on its action on phospholipids metabolic pathways of the parasite; miltefosine is a lipophilic and hydrophobic molecule and therefore is able to penetrate cell membranes and cause a fast metabolism of other phospholipids (18).

Miltefosine interrupts cell signaling pathways and the synthesis of cell membranes of the protozoa through different points of action: It inhibits the biosynthesis of GFI fixers (Glycosylphosphatidylinositol), mainly for the intracellular survival of amastigotes.

It alters the transduction of the signaling at the phospholipase $\mathrm{C}$ and protein kinase $\mathrm{C}$ specific levels of Leishmania, regulating and controlling its growth and cell differentiation.

It inhibits the biosynthesis of hosphatidylcholine, a molecule of the lipid bilayer of the cell membrane of the protozoa (18).

Due to various organs and tissues to where the Leishmania protozoa can travel to, it is recommended that the treatment last approximately 28 days to ensure the efficiency of the treatment and not cause resistance (18).

In current clinical veterinary practice, due to the restriction of these drugs, the implementation of the treatments is more difficult; therefore, alternatives should be explored. In Europe miltefosine exists for veterinary use (Milteforan ${ }^{\circledR}$ ); nevertheless, this drug is not available in Colombia maybe because of the repercussions it could have due to the armed conflict and the indiscriminate use by third parties. The dosage is $2 \mathrm{mg} / \mathrm{kg} /$ day by mouth during 28 days combined with allopurinol to $10 \mathrm{mg} / \mathrm{kg} / \mathrm{day}$ by mouth for 6 to 12 months.

One of the alternatives that could be used are medicinal plants since they respect the liver and kidney health and they have healing properties and acción sobre las vías metabólicas fosfolipídicas del parásito; es una molécula lipofílica e hidrofóbica, y por ello es capaz de penetrar membranas celulares y causar el rápido metabolismo de éter-fosfolípidos (18).

La Miltefosina interrumpe las vías de señalización celular y la síntesis de la membrana celular del protozoo a través de distintos puntos de acción: Inhibe la biosíntesis de fijadores GFI (glicosil-fosfatidil-inositol), fundamental para la supervivencia intracelular de los amastigotes.

Altera la transducción de la señal a nivel de fosfolipasa $C$ y proteinkinasa $C$ específicas de la Leishmania, haciendo una regulación y control de su crecimiento y diferenciación celular.

Inhibe la biosíntesis de fosfatidilcolina, molécula de la bicapa lipídica de la membrana celular del protozoo (18).

Debido a los diversos órganos y tejidos a donde pueden llegar los protozoos de Leishmania, el tratamiento, se recomienda, que dure aproximadamente 28 días, para asegurar su eficacia y no generar resistencia (18).

En la práctica clínica veterinaria, por la restricción del uso de estos medicamentos, la implementación de los tratamientos se hace difícil, por lo que se deben buscar alternativas. En Europa la miltefosina existe en presentación de uso veterinario (Milteforan ${ }^{\circledR}$ ), sin embargo ese medicamento no está disponible en Colombia tal vez por las repercusiones que pueda tener debido al conflicto armado y el uso indiscriminado por parte de terceras personas. La dosis es de $2 \mathrm{mg} / \mathrm{kg} /$ día por vía oral durante 28 días combinado con alopurinol a $10 \mathrm{mg} / \mathrm{kg} /$ día por vía oral durante 6 a 12 meses.

Una de las alternativas que se podrían utilizar son las plantas medicinales, ya que respetan la salud hepática y renal y a las cuales se les atribuye propiedades curativas y tienen fácil acceso, aunque no hay estudios en animales podrían ser una alternativa (27).

Otra alternativa en el tratamiento es la domperidona, la cual funciona como inmunomodulador en forma oral. Actualmente está disponible para el tratamiento y prevención de la Leishmaniasis en Europa y otros países (Leisguard ${ }^{\circledR}$ ). La domperidona actúa como un antagonista de la dopamina, la cual promueve la liberación de serotonina, que estimula la producción de prolactina. Esta última promueve la respuesta inmune celular Th1, con las respectivas IL-2, IL-12, INF-y y TNF, lo que lleva a la activación de los macrófagos y la muerte celular respectiva. Es un medicamento que tiene la ventaja de ser 
are easily available; although, there are no studies in animals, they could be an alternative (27).

Domperidone is another alternative in the treatment that works as an immunomodulatory in oral form. Currently, domperidone (Leisguard ${ }^{\circledR}$ ) is available for the treatment and prevention of Leishmaniasis in Europe and other countries. Domperidone acts as an antagonist of dopamine, which promotes the release of serotonin that stimulates the production of prolactin. The later promotes a Th1 cell immune response with the respective IL-2, IL-12, INF-Y and TNF, which causes the activation of macrophages and the corresponding cell death. Domperidone is a drug that has the advantage that it is taken by mouth; it's inexpensive and can be used in patients with kidney failure, which is one of the most common complications in the treatment of canines with leishmaniasis. In animals that have not been infected, the treatment can work as a preventive measure since it increases the phagocytic capacity of neutrophils and monocytes, thus increasing the resistance to the infection. The dosage is $0.5 \mathrm{mg} /$ kg every 24 hours for 30 consecutive days during times when the activity of the vectors increases (in countries where the vectorial activity is seasonal) $(28,29)$; perhaps in tropical countries where there is abundance of vectorial activity during the whole year, a preventive treatment would need to be evaluated or other tools would need to be used.

The study demonstrated that domperidone makes the dog 7 times less susceptible to infection than in those canines that did not receive the treatment, while the vaccine makes them 4 times less susceptible. Likewise, domperidone proved to be efficient in the reduction of antileishmania antibodies during the first stages of the infection, thus possibly reducing the risk of deposit of immune complexes and controlling the subclinical infections (30).

In summary, it is important to consider the clinical classification according to the diagnosis in order to implement the treatment the correct way as follows:

Dogs that have been exposed or with subclinical infection: do not necessarily need therapy; they must be monitored and subject to serological testing.

Dogs with evident infection: therapy is carried out if there is an increase in antibody titers.

Sick dogs: need anti-leishmania therapy and support therapy if necessary

Dogs with serious disease: need anti-leishmania therapy and support therapy in case of kidney or liver failure administrado vía oral, no es costoso y puede ser utilizado en pacientes con insuficiencia renal, que es una de las complicaciones más frecuentes en el tratamiento de caninos con leishmaniosis. En los animales no infectados puede funcionar como método preventivo ya que aumenta la capacidad fagocítica de los neutrófilos y los monocitos, aumentando así la resistencia a la infección. La dosis es de 0.5 $\mathrm{mg} / \mathrm{kg}$ cada 24 horas por 30 días consecutivos, en las épocas donde se aumenta la actividad de los vectores (en países donde esta actividad vectorial es estacional) $(28,29)$, tal vez en países tropicales donde la abundancia vectorial es durante todo el año habría que evaluar la administración preventiva o hacer uso de otras herramientas.

En un estudio se demostró que el uso de domperidona hace al perro 7 veces menos susceptible a la infección que en aquellos caninos que no recibieron el tratamiento, mientras que la vacuna los hace 4 veces menos susceptibles. De igual manera la domperidona demostró ser eficaz en la reducción de anticuerpos antileishmania en los primeros estadios de la infección, reduciendo posiblemente el riesgo de depósito de complejos inmunes y controlando así infecciones subclínicas (30).

En síntesis, es importante considerar la clasificación clínica según el diagnóstico para poder implementar el tratamiento de la manera correcta así:

Perros expuestos o con infección subclínica: no necesariamente necesitan terapia, hay que monitorearlos y hacer evaluación serológica.

Perros con infección evidente: se realiza terapia si hay aumento en los títulos de anticuerpos.

Perros enfermos: necesitan terapia antileishmania y terapia de soporte si es necesario

Perros con enfermedad grave: necesitan terapia antileishmania y terapia de soporte en caso de insuficiencia renal o hepática

Perros que no responden al tratamiento o tuvieron una recaída: reevaluar la terapia, verificar si existe otra enfermedad concomitante, evaluar exámenes de laboratorio, considerar una cepa resistente a los antimoniales.

Un esquema terapéutico podría ser antimoniato de meglumina a dosis de $100 \mathrm{mg} / \mathrm{kg}$ cada 24 horas SC por 4 semanas y el alopurinol a dosis de $10 \mathrm{mg} / \mathrm{kg}$ cada 12 horas por vía oral durante mínimo 6 meses a 1 año. Este protocolo puede mostrar una cura clínica hasta por un año, así mismo disminuye la cantidad de parásitos por varios meses, lo cual reduce el riesgo de transmisión del parásito a los vectores (21). 
Dogs that do not respond to the treatment or had a relapse: reevaluate the therapy, verify if there is another parallel disease, evaluate lab tests, consider a stain resistant to antinomies

A therapeutic scheme could be a dosage of $100 \mathrm{mg} / \mathrm{kg}$ every 24 hours SC for 4 weeks of meglumine antimoniate and a dosage of $10 \mathrm{mg} /$ kg every 12 hours by mouth of allopurinol during at least 6 months to 1 year. This protocol can show a clinical cure of up to one year; also, the amount of parasites will be reduced for several months, which reduces the risk of transmission of the parasite to the vectors (21).

\section{The vaccination in cases of Leishmania}

In European countries, vaccination can be considered as an alternative method for prevention; nevertheless, in Colombia, there are no studies on the subject; additionally, the possibility of elaborating a vaccine from native stains of the tropics should be considered. The vaccines currently available are: Leishmune ${ }^{\circledR}$ (Fort Dodge), which was approved in 2003, contains an immunogen Fucose Mannose Ligand (FML), Leishmania donovani glycoprotein, associated with a coadjutant saponine based; Complexion ${ }^{\circledR}$ Leish, approved in 2007 and composed of the A2 Antigen (a specific recombinant protein of amastigote state from different types of Leishmania, also as a coadjutant spanning based; these vaccines are not effective in the protection of the disease and although both vaccines comply with the technical requirements for their registration and to be on the market, the need to differentiate between the natural infection due to $L$. infantum and the vaccine immune response through serological tests and to evaluate if the vaccines reduce the incidence of the infection and the disease in canines is necessary. Likewise, to obtain absolute results that the biologics are capable of blocking the cycle of the disease in the parasite's transmission phase (31).

In 2014, a review of the efficiency of the prophylactic measures for canine leishmaniasis was conducted. 937 publications were included where all the prevention and control strategies against canine leishmaniasis were gathered, including vaccination, topical insecticides and preventive treatments. 12 of these documents were considered relevant to the vaccination subject. The main result to evaluate was the proportion of dogs infected with $L$. infantum, whether based on the serology or the detection of parasites, after the vaccination period; nevertheless, only 6 studies showed a significant protective effect based on the parameters mentioned above. In spite of these reports that

\section{La vacunación en casos de Leishmania}

La vacunación puede considerarse como una alternativa como método de prevención en países europeos, más sin embargo en Colombia no hay estudios respecto al tema; adicionalmente se debe considerar la posibilidad de elaborar una vacuna a partir de cepas nativas del trópico. Las vacunas actualmente disponibles como: Leishmune ${ }^{\circledR}$ (Fort Dodge), la cual fue aprobada en el año 2003, contiene un inmunógeno Ligando de Fucosa-Manosa (FML), glicoproteína de Leishmania donovani, asociado con un coadyuvante a base de saponina; $\operatorname{Tec}^{\circledR}$ Leish, aprobada en 2007 y compuesta por el Antígeno A2 (una proteína específica recombinante del estado amastigote de diferentes especies de Leishmania, también con un coadyuvante a base de saponina; no son eficaces en la protección de la enfermedad y aunque ambas vacunas cumplieron con los requisitos técnicos para su registro y para ser lanzadas al mercado, es necesario distinguir entre la infección natural por L. infantum y la respuesta inmune vacunal a través de pruebas serológicas, así como evaluar si las vacunas reducen la incidencia de la infección y de la enfermedad en los caninos. De la misma forma obtener resultados absolutos de que los biológicos son capaces de bloquear el ciclo de la enfermedad en la etapa de transmisión del parásito (31).

En el 2014 se realizó una revisión acerca de la eficacia de las medidas profilácticas para la leishmaniosis canina. Se incluyeron 937 publicaciones donde se reunieron todas las estrategias de prevención y control contra la leishmaniosis canina, incluyendo la vacunación, insecticidas tópicos y tratamientos preventivos, 12 de estos documentos se consideraron relevantes acerca del tema de la vacunación. El principal resultado a evaluar fue la proporción de perros infectados con $L$. infantum, ya sea basado en la serología o la detección de parásitos, luego de un período de vacunación, sin embargo, sólo 6 estudios mostraron un efecto protector significativo basado en los parámetros anteriores. A pesar de estos reportes disponibles, varios tienen deficiencias en su diseño metodológico, estadístico, diagnóstico y evaluación de la respuesta inmune. Por ejemplo, algunas de las vacunas disponibles provocan una respuesta humoral que, aún con los métodos actuales disponibles, no diferencia claramente entre infección activa y la vacunación. Algunos estudios apoyan el uso de la vacunación para prevenir la infección por L. infantum (Leishmune ${ }^{\circledR}$, CaniLeish $\left.{ }^{\circledR}\right)$, sin embargo, las deficiencias metodológicas de estos reportes sobre estas intervenciones deben tenerse en cuenta. 
are available, several have deficiencies in their methodological, statistical, diagnostics and evaluation design to the immune response. For example, some of the available vaccines provoke a humoral response that, even with the current available methods, does not clearly differentiate between the active infection and the vaccination. Some studies support the use of vaccination to prevent infection from $L$. infantum (Leishmune ${ }^{\circledR}$, CaniLeish ${ }^{\circledR}$ ); nevertheless, the methodological deficiencies of these reports about these interventions must be considered. Additionally, although these vaccines could have prevented the infection, they do not prove that they can prevent the later transmission of the infection or cure the infected patient (32).

\section{Considerations about euthanasia}

In Latin America, especially in Brazil and Argentina, euthanasia is currently considered as an alternative, even if there is a medical treatment available. Also, by informing the population about the disease and its variables, prevention and control strategies can be implemented in addition to informing the health authorities (33).

Nevertheless, the disease is not handled the same way in all countries. Some countries consider euthanasia as the best option in canines to avoid the installation and propagation of the disease in an area, especially in urban areas. Nevertheless, this type of strategy sometimes is enough as a method of prevention and control of canine Leishmaniasis $(33,34)$.

Failures in handling euthanasia as an eradication method are the non-acceptance of the method by the citizens, low sensibility to the diagnostic tests, late detection of the disease and replacement of the sacrificed canine by a susceptible one, that could even be a puppy. In this field, public, private, corporate and community interests of the State also have an influence. Labs and animal protection groups (protectionist) also have an influence one-way or the other in the decision making process with respect to the disease. The role of the veterinary doctor in this situation is very complex, because he also must participate in the decision making process of carrying out or not the euthanasia or the adequate treatment for the canine, if such treatment is available (34).

The migration of the population to urban centers bringing with them their belongings and their pets, makes the disease propagate even faster than expected. This will be reflected in an increase of the public health problem every day, in the sense that pets that are not infected are at high risk of
Adicionalmente, aunque estas vacunas pudieran prevenir la infección, no demuestran que puedan prevenir la transmisión posterior a la infección o curar al paciente infectado (32).

\section{Consideraciones acerca de la eutanasia}

En América Latina, y en especial en Brasil y Argentina, actualmente se considera la eutanasia como una alternativa, aunque pueda estar disponible el tratamiento médico. Además, informando a la población sobre la enfermedad y sus variables se pueden implementar estrategias de prevención y control, además de informar a la autoridad sanitaria (33).

No obstante, no en todos los países se maneja de la misma manera, en algunos consideran la eutanasia como la mejor opción en caninos para evitar la instalación y propagación de la enfermedad en una zona, principalmente urbana. Sin embargo, este tipo de estrategia muchas veces es insuficiente como método de prevención y control de la Leishmaniosis canina $(33,34)$.

Las fallas de manejar la eutanasia como un método de erradicación son la no aceptación por parte de la ciudadanía, baja sensibilidad de las pruebas diagnósticas, detección tardía de la enfermedad y el reemplazo del canino sacrificado por uno susceptible, que inclusive puede ser un cachorro. En este campo también influyen los intereses públicos, privados corporativos y comunitarios del Estado, laboratorios y animalistas (proteccionistas) influyen de una u otra manera en la toma de decisiones respecto a la enfermedad. El rol del médico veterinario en esta situación es bastante complejo ya que él también debe participar en la toma de decisiones frente a la realización o no de la eutanasia o del adecuado tratamiento para el canino si es que éste se encuentra disponible (34).

La migración de la población a cascos urbanos, trayendo con ellos sus enseres y sus mascotas hace que la enfermedad se propague aún más rápido de lo esperado, lo que se ve reflejado en que este problema de salud pública empeore cada día más, llevando a que mascotas que no se encuentran infectadas estén en un alto riesgo de contraer la enfermedad, para el caso de zonas urbanas donde se encuentre el vector (35).

Desafortunadamente en países en vía de desarrollo se enfocan en el sacrificio de los caninos independientemente de si tiene el efecto esperado o no, además que los entes territoriales no destinan dinero para el tratamiento en los perros. Es necesario tener en cuenta que también 
getting the disease, for the case of urban centers where the vector can be found (35).

Unfortunately in developing countries the focus is in the slaughtering the canines regardless of the expected effect, in addition to the fact that territorial entities do not provide funding for the treatment in dogs. It is necessary to also consider that in some countries the state has prohibited the treatment of canines with drugs for human use, making its management more complex and therefore, forcing veterinary doctors and the health authorities to recommend and conduct euthanasia in infected patients. Epidemiology and social classes play a very important role in the decision making process with respect to the sick pet, since they consider the pet as another member of the family and therefore, will do everything possible to get the treatment and avoid losing it at all cost. This way, they exert pressure on the industry to keep looking for the most efficient treatment against Leismania, and also that the treatment be available to any person. Among these social classes it's also important to remember that street dogs are a means for dissemination of the disease. But many of these street dogs are "adopted" by some persons or some neighborhoods that will prevent its slaughter, without any treatment being carried out (35).

A strategy to avoid euthanasia is to alert the population about the responsible care of pets, because when pets are not kept at all times at home and are left wandering in the rural or urban environment, there is a greater risk of transmission and proliferation of the disease in endemic zones. Another way is to use repellents, adequate nutrition and all the necessary measures that can maintain the a competent immune system of the dog, which, although it works in other countries, given the number of dogs infected with the visceral form somewhat dismiss these premises. (35).

Given the possibility of considering this option, there are several aspects to consider:

The animal: Considering that animals, as with humans, have the right not to suffer and that humans have a moral obligation of not inflicting unnecessary suffering, it will be necessary to evaluate the benefits of this treatment versus the benefits of euthanasia and the benefits of the absence of the transmission of the disease in the population.

Owners: must be conscious of hygiene rules and precautions that must be taken, the cost of the treatment if available, the probability of success en algunos países el estado ha prohibido el tratamiento en caninos con medicamentos de uso humano, haciendo mucho más complejo su manejo y por ende obligando a los médicos veterinarios y a las autoridades sanitarias recomendar y realizar la eutanasia en pacientes infectados. La epidemiología y las clases sociales juegan un papel muy importante en cuanto a la toma de decisiones en torno a la mascota enferma, ya que la consideran como un miembro más de la familia y por ende harán lo posible por realizar un tratamiento y evitar a toda costa perderlo, de este modo presionan de algún modo a la industria para seguir buscando el tratamiento más eficaz contra la Leishmania, además de que sea un tratamiento que esté al alcance de cualquier persona. Dentro de estas clases sociales también es importante recordar que los perros callejeros son un medio de diseminación de la enfermedad, pero que muchos de estos son "adoptados" por algunas personas o algunos vecindarios impidiendo su sacrificio, sin que se les realice algún tipo de tratamiento (35).

Una estrategia para evitar la eutanasia es haciendo un llamado a la población sobre la tenencia responsable de mascotas, ya que al no tenerlas en casa todo el tiempo y dejándolas en el ambiente rural o urbano tienen un mayor riesgo de contagio y proliferación de la enfermedad en zonas endémicas, otra manera es la utilización de repelentes, una adecuada nutrición, y todas aquellas medidas que puedan mantener el sistema inmune del perro competente, lo cual, aunque funciona en otros países, también el número de casos de perros infectados con la forma visceral, desestima un poco estas premisas (35).

Ante la posibilidad de considerar esta opción, hay varios aspectos que se deben tener en cuenta: El animal: Teniendo en cuenta que los animales, como los humanos, tienen derecho a no sufrir y que los humanos tienen una obligación moral de no infligir un sufrimiento innecesario, será necesario evaluar los beneficios del tratamiento versus los beneficios de la eutanasia y los beneficios de la ausencia de la transmisión de la enfermedad en la población.

Los propietarios: deben ser conscientes de las normas de higiene y las precauciones que deben tomar, el costo del tratamiento si está disponible, la probabilidad del éxito del mismo, el uso o destino del animal si es posible la curación.

El Médico Veterinario: deberá tener en cuenta la salud del animal, la relación con el propietario y la responsabilidad en la protección de la salud pública. 
of the treatment, the use or destination of the animal if a cure is possible.

The Veterinary Doctor: must consider the health of the animal, the relationship with the owner and the responsibility in the protection of public health

Animal population: the potential of an epizootic outbreak in the population at risk must be considered.

Public Health: the risks for the human population (36).

In Colombia, the regulation regarding zoonotic diseases (Decree 2257 of 1986), in addition to being a mandatory the notification of a zoonotic disease, article 49 establishes the elimination by the health authorities of those animals that present a zoonotic disease, with or without owner, as the case may be. Also, chapter $V$ of Law 84 of 1989 considers the slaughtering of animals in similar cases or situations such as those produced by leishmaniasis, like: incurable diseases, self-defense o defense of a third person (transmission of a disease to other persons) and in case of a threat to public health. Nevertheless, these criteria are to be considered and decided by the veterinary doctor responsible for the case.

\section{What to do when faced with suspicious case?}

If there is a suspicious patient with this disease at the veterinary clinic, some considerations must be noted: The possibility of an adequate diagnosis, the availability of the treatment, the zone where the canine comes from and the place where the canine lives or is destined to live, make the owners aware of the disease, the risks to the community and other animals. In Colombia, some simple techniques that have been described above can be conducted for the diagnosis or resort to research Centers or reference Centers that can carry out a proper diagnosis (INS, CIDEIM, PECET, for example). With respect to the treatment, its necessary to be conscious that the availability of treatment is little or none; therefore, some alternatives can be sought such as improve the patient's immune system, nutrition and, definitely, inform the health authorities about the case if positive and avoid returning patient to endemic zones in light of the risk of being a source of parasites to the vectors. In figure 5 a scheme of the steps that could be followed if faced with a suspicious case can be observed.
La población animal: se debe considerar el potencial de presentarse una epizootia en la población a riesgo.

La Salud Pública: los riesgos para la población humana (36).

En Colombia, la normatividad en cuanto a zoonosis se refiere (Decreto 2257 de 1986), además de ser una zoonosis de notificación obligatoria, en el artículo 49 se plantea la eliminación por parte de las autoridades sanitarias de aquellos animales que presenten zoonosis, con o sin dueño, según sea el caso. De igual manera la Ley 84 de 1989 , en su capítulo V considera el sacrificio de animales para casos o situaciones similares a las producidas por la leishmaniosis, tales como: enfermedades incurables, defensa propia o de un tercero (transmisión de la enfermedad a otras personas) y en caso de amenaza a la salud pública. Sin embargo, estos criterios quedan a disposición y decisión del médico veterinario responsable del caso.

\section{¿Qué hacer ante un caso sospechoso?}

Cuando en la clínica veterinaria se nos presenta un paciente sospechoso de esta enfermedad debemos tener algunas consideraciones. La posibilidad de un diagnóstico adecuado, la disponibilidad del tratamiento, la zona de donde proviene el canino y el lugar donde vive o va a ser destinado, sensibilizar a los propietarios acerca de la enfermedad, los riesgos a la comunidad y a los otros animales. En Colombia, para el diagnóstico se pueden realizar algunas técnicas sencillas descritas anteriormente o recurrir a Centros de investigación o Centros de referencia que puedan realizar el diagnóstico adecuadamente (INS, CIDEIM, PECET, por ejemplo). Con respecto al tratamiento hay que ser conscientes de que la disponibilidad es poca - nula, por lo que se podrían buscar algunas alternativas, mejorar la inmunidad del paciente, nutrición; y definitivamente, informar a la autoridad sanitaria acerca del caso si es positivo y evitar que el paciente regrese a zonas endémicas ante el riesgo de ser fuente de parásitos a los vectores. En la figura 5 se puede observar un esquema de los pasos que se podrían seguir ante un caso sospechoso.

\section{Prevención y control}

Debido a que en Colombia aún no se dispone de vacuna para prevenir la enfermedad y la posibilidad de realizar el tratamiento es muy baja, se pueden aplicar diversos métodos que actúan como barrera 


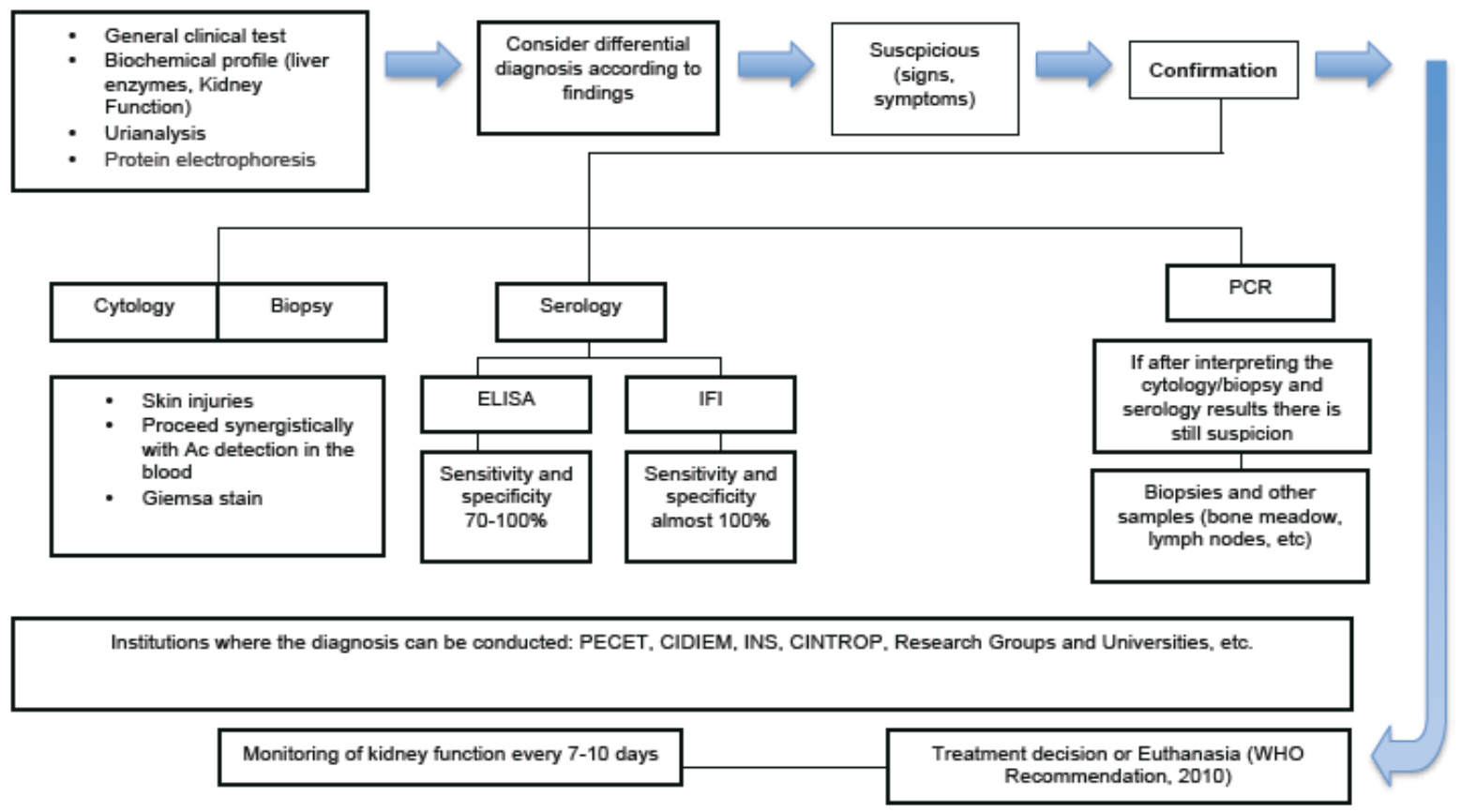

Figure 5. Proposed scheme for steps to follow when faced with a suspicious case of canine leishmaniasis.

\section{Prevention and control}

Considering that in Colombia a vaccine to prevent the disease is not yet available and the possibility of treatment is very low, several methods that act as a barrier between the vector and the host can be applied, such as: external use repellents $\left(\right.$ Advantix ${ }^{\circledR}$ ), other repellents (chemical and natural), pyrethroids topical treatments, use of insecticides in kennels or canines, appropriate size barriers or nets treated with residual pyrethroids, mosquito nets, permethrin and deltramethrin based ectoparasiticides collars, such as the protective collar Scalibor ${ }^{\circledR}$. Scalibor ${ }^{\circledR}$ protects animals for up to six months, is resistant to water and has a repellent action against sand-fly, ticks and fleas. Likewise, healthy and immunocompetent dogs with updated sanitary schemes and right nutrition are less susceptible.

In 2014, Willy et al (37), made a review about the efficiency of preventive measures such as the topical application of insecticides (colors, spot-on) and prophylactic drugs (domperidone, allopurinol). Generally, collars are made from deltametrine and spot-on formulas are made from permethrin or permethrin together with imidaclopride. One of the ways to measure the results was the difference in the proportion of dogs infected with $L$. infantum, whether based on the serology or the detection of parasites. It was shown that deltametrine collars have a protective effect, the same as spot-on formulations. Only entre el vector y el hospedero, tales como: pipetas repelentes de uso externo (Advantix ${ }^{\circledR}$ ), otros repelentes (químicos o naturales), formulaciones tópicas a base de piretroides, uso de insecticidas en las perreras o caniles, barreras o redes del tamaño adecuado tratadas con piretroides residuales, toldillos, collares ectoparasiticidas a base de permetrina y deltrametrina, como por ejemplo el collar protector Scalibor ${ }^{\circledR}$, el cual protege a los animales hasta por seis meses, es resistente al agua y posee acción repelente contra flebótomos, garrapatas y pulgas. De igual manera perros sanos, inmunocompetentes, con esquemas sanitarios al día y adecuada nutrición, son menos susceptibles.

Wylie et al (37) en 2014 realizaron una revisión acerca de la eficacia de las medidas preventivas tales como la aplicación tópica de insecticidas (collares, spot-on) y medicamentos profilácticos (domperidona, allopurinol). En general los collares están hechos a base de deltametrina y las formulaciones spot-on a base de permetrinas o permetrinas junto con imidacloprid. Una de las formas de medir los resultados fue la diferencia en la proporción de perros infectados con $L$. infantum, ya sea basado en la serología o en la detección de parásitos. Se evidenció que los collares a base de deltametrina tienen un efecto protector, al igual que las formulaciones en spot-on. Sólo uno de los tres estudios revisados sobre el uso de medicación profiláctica mostró un efecto estadísticamente significativo, con un efecto protector evidente con base en la domperidona. De igual manera, los 
one of three studies reviewed about the use of prophylactic medication showed a significant statistical effect, with an evident protective effect based on domperidone. Also, dogs that live in endemic zones are commonly treated with collars and spot-on formulations as complimentary measures. There are studies that support the use of control measures to prevent infection from $L$. infantum both in endemic zones as well as in non-endemic zones, mainly, collars based on deltametrine, permetrine $65 \%, 10 \%$ imidaclopride with $50 \%$ spot-on permetrine and domeperidone as a preventive drug.

\section{Conclusions}

Since Leishmaniasis is considered as a anthropozoonosis disease, it is very important to consider its effects to human health and animals in the geographic zone where it is present.

Diverse clinical forms of leishmaniasis present a serious problem to public health around the world. The World Health Organization (WHO), in its Tropical Disease Research, has classified leishmaniasis in category I as an emerging disease without control (7).

In Colombia, an increase of notified cases in the last five years reflects a considerable increase, which can be attributed to several factors, such as, the increase of human activities in wild areas where enzootic transmission exists, the adaptation of the vectors to new places and the urbanization of parasites in the cutaneous form (7).

In Colombia, decree 2257 of 1986 regulates diseases of the zoonotic type. Article 49 of such decree states that in areas with zoonosis problems transmitted by dogs, health authorities may restrict the animal population by individual or collective capture and sanitary elimination of such animals that do not have an owner. This is where the responsibility of veterinary doctors in the education of responsible pet ownership derives from. According to the above, this disease is of mandatory notification.

In Colombia, the veterinary clinic must differentiate cases of canines infected with visceral leishmaniasis ( $L$. infantum) from cases of canines infected with cutaneous stains ( $L$. panamensis, $L$. braziliensis). As recommended by the World Health Organization, treatment for cases compatible with visceral leishmaniasis is euthanasia since NO other treatment is available and the role that the canine has as a source of parasites to the vector, which is considered as a dangerous epidemiological situation (38). For cases of canines compatible with cutaneous stains perros que viven en zonas endémicas se tratan comúnmente con collares y formulaciones spoton como medidas complementarias. Hay estudios que apoyan el uso de medidas de control para prevenir la infección por $L$. infantum tanto en zonas endémicas como no endémicas, en particular, collares a base de deltametrina, permetrina $65 \%$, $10 \%$ imidacloprid con un $50 \%$ permetrina en spoton y la domperidona como medicamento de uso preventivo.

\section{Conclusiones}

Al considerarse una enfermedad antropozoonótica, es de gran relevancia tener en cuenta los efectos para la salud humana y animal en la zona geográfica donde se presenta.

Las diferentes formas clínicas de la leishmaniosis presentan un serio problema de salud pública en el mundo. La Organización Mundial de la Salud (OMS), en el Tropical Disease Research, han clasificado la leishmaniosis en la categoría I como una enfermedad emergente y sin control (7).

En Colombia el aumento de los casos notificados en los últimos cinco años refleja un aumento considerable, que se puede atribuir a diversos factores, entre ellos, al aumento de las actividades humanas en zonas silvestres en donde existe la transmisión enzoótica, la adaptación de los vectores en nuevos lugares, y la urbanización de la parasitosis en la forma cutánea (7).

En Colombia, existe el decreto 2257 de 1986, el cual regula las enfermedades de tipo zoonótico, en el cual se estipula en el artículo 49 que en áreas con problemas de zoonosis transmitidas por perros, las autoridades sanitarias podrán restringir la población animal, por medio de capturas individuales o colectivas y eliminación sanitaria de aquellos que se consideren que no tienen dueño, lo que deriva en la responsabilidad que tienen los médicos veterinarios en educar en tenencia responsable de mascotas. Según la norma anterior, esta enfermedad es de notificación obligatoria.

En Colombia, en la clínica veterinaria se deben diferenciar los casos de caninos infectados con leishmaniosis visceral ( $L$. infantum) de los casos de caninos infectados con cepas cutáneas ( $L$. panamensis, $L$. braziliensis), el tratamiento de los casos compatibles con leishmaniosis visceral es la eutanasia, debido a la NO disponibilidad del tratamiento y al papel que desempeña el canino como fuente de parásitos al vector, lo cual se considera una situación epidemiológica peligrosa, tal como lo recomienda la Organización Mundial de la Salud (38). Para el caso de caninos compatibles con cepas cutáneas el tratamiento es sintomático, 
the treatment is symptomatic, thermotherapy in injuries (heat, nitrogen), increase of immunity, etc. Currently, the purpose of the research is the search for effective treatments for veterinary use that do not generate resistance and that replace the slaughtering of animals.

\section{Acknowledgments}

To the Center for Canine Training and Retraining (CERCA) of the School of Military Engineers (ESING), for figures 1, 3 and 4. To Dr. Bruno Travi, Depts. of Internal Medicine (Infectious Diseases), \& Microbiology and Immunology, University of Texas Medical Branch (UTMB); for his comments and for figure 2. To Dr, Martha Stella Ayala Sotelo, of the Parasitology Group of the National Institute of Health (INS) of Colombia, for her comments and recommendations. To Dr. Iván Darío Vélez, Study and Control of Tropical Diseases Program (PECET) of the University of Antioquia, for his comments and recommendations on the article. termoterapia en las lesiones (calor, nitrógeno), aumentar la inmunidad, etc. Actualmente, es objeto de investigación, la búsqueda de tratamientos de uso veterinario, eficaces, que no provoquen resistencia y que reemplacen el sacrificio de los animales.

\section{Agradecimientos}

Al Centro de Entrenamiento y Reentrenamiento Canino (CERCA) de la Escuela de Ingenieros Militares (ESING), por las figuras 1, 3 y 4 . Al Dr. Bruno Travi, Depts. of Internal Medicine (Infectious Diseases), \& Microbiology and Immunology, University of Texas Medical Branch (UTMB); por sus comentarios y la figura 2. A la Dra. Martha Stella Ayala Sotelo, del Grupo de Parasitología del Instituto Nacional de Salud (INS) de Colombia, por sus comentarios y recomendaciones. Al Dr. Iván Darío Vélez, Programa de Estudio y Control de Enfermedades Tropicales (PECET) de la Universidad de Antioquia, por sus comentarios y recomendaciones al manuscrito.

\section{REFERENCES}

1. Vélez ID, Carrillo LM, López L, Rodríguez E, Robledo SM. An Epidemic Outbreak of Canine Cutaneous Leishmaniasis in Colombia Caused by Leishmania braziliensis and Leishmania panamensis. Am J Trop Med Hyg 2012; 86(5):807-811.

2. Solano-Gallego L, Miró G, Koutinas A, Cardoso L, Grazia MP, Ferrer L, et al. LeishVet guidelines for the practical management of canine leishmaniosis. Parasites \& Vectors 2011; 4:86.

3. Ribeiro AS, Melo MN. Non-Invasive Molecular Diagnosis of Canine Visceral Leishmaniasis Using Conjunctival Swab Samples. En: Claborn D. Leishmaniasis-Trends in Epidemiology, Diagnosis and Treatment. InTech. 2014. 195-216.

4. Salomón OD, Mastrángelo AV, Santini MS, Ruvinsky S, Orduna T, Sinagra A, et al. Leishmaniasis visceral: senderos que confluyen, se bifurcan. Salud Colectiva 2012; 8(1):49-63.

5. Instituto Nacional de Salud (INS). Guía Protocolo para la vigilancia en salud pública de leishmaniasis. Subdirección de Vigilancia y Control en Salud Pública. 2011; 1-29.
6. Vélez ID, Zuleta, M. Geografía de la expansión de la Leishmaniasis en el conflicto armado en Colombia (Antioquia). Eu-topías 2013; 7:99-111.

7. Romero M, Sánchez JA. Una mirada a la epidemiología y al control de la Leishmaniasis zoonótica en Colombia. Biosalud 2007; 6:99111.

8. Pennisi MG. Leishmaniosis of companion animals in Europe: An update. Vet Parasitol. 2015; 208(1-2):35-47.

9. Vélez ID, Robledo SM. Leishmaniasis. Rev Leprol 2010; 27(4):367-396.

10. The Center for Food Security \& Public Health (CFSPH). Leishmaniasis (cutánea y visceral). Iowa state University. College of Veterinary Medicine. 2009; 1-13.

11. Dalmau A, Ossó M, Oliva A, Anglada L, Sarobé $X$, Vives $E$. Leishmaniosis felina a propósito de un caso clínico. ¿Nos olvidamos de que existe?. Clin Vet Peq Anim 2008; 28(4):233-237. 
12. Rodríguez IE. Respuesta inmune a la infección por Leishmania infantum en caninos. REDVET. Revista Electrónica de Veterinaria 2009; 10(1):1-8.

13. Rosypal A. Characterization of Canine Leishmaniasis in the United States: Pathogenesis, Immunological Responses, and Transmission of an American Isolate of Leishmania infantum. [Tesis Doctoral]. Virginia Polytechnic Institute \& State University. EEUU. Blacksburg, VA; 2005.

14. Baneth G, Koutinas A, Solano-Gallego L, Bourdeau P, Ferrer L. Canine leishmaniosis - new concepts and insights on an expanding zoonosis: part one. Trends Parasitol 2008; 24(7):324-330.

15. Honse CO, Figueiredo FB, Alencar NX, Madeira MF, Gremião ID, Schubach TM. Disseminated intravascular coagulation in a dog naturally infected by Leishmania (Leishmania) chagasi from Rio de Janeiro - Brazil. Vet Res 2013; 9(43):1-5.

16. Soares MJ, Moraes Jr, Moraes FR. Renal involvement in canine leishmaniasis: a morphological and immunohistochemical study. Arq Bras Med Vet Zootec 2009; 61(4):785-790.

17. Miró G. Leishmaniosis canina: situación actual en Europa, diagnóstico y control. Acta Scientiae Veterinariae 2007; 35(Supl 2):s227-s229.

18. Pérez T, Marchesi D, Iglesias M. Primera Descripción del Uso de la Miltefosina en una Paciente con Leishmaniosis Canina, Infección Renal y Trichuris: Un Caso Complicado. Vet Arg 2009; XXVI(259):1-6.

19. Miró G, Cardoso L, Grazia M, Oliva G, Baneth G. Canine leishmaniosis - new concepts and insights on an expanding zoonosis: part two. Trends Parasitol 2008; 24(8):371-377.

20. Chouihi E, Amri F, Bouslimi N, Siala E, Selmi K, Zallagua N, et al. Cultures on NNN medium for the diagnosis of leishmaniasis. Pathol Biol 2009; 57(3):219-24.

21. Roura, X. Diagnóstico y tratamiento de la leishmaniosis canina: actualización. Vet Arg 2012; 1-6.

22. León M. Nuevos avances en la asociación antimoniato de meglumina + alopurinol: el tratamiento de referencia para la leishmaniosis canina. Consulta Difus Vet 2010; 173:37-39.
23. Castagnaro M, Crotti A, Fondati A, Gradoni L, Lubas G, Maroli M, et al. Canine leishmaniasis: Guidelines for diagnosis, staging, therapy, monitoring and prevention.[on line]. Canine Leishmaniasis Working Group; 2007. URL Available in: http://www.gruppoleishmania.org/ files/veterinaria_2007_eng.pdf

24. Vásquez $L$, Vicuña-Fernández $N$, Petit $Y$, López S, Scorza J, Scorza-Dager J, et al. Disposición farmacocinética de las especies de antimonio en perros después de una dosis de antimoniato de meglumina (Glucantime $\AA$ ). Bol Mal Salud Amb 2008; 48(1):27-33.

25. Soto J, Soto P. Miltefosina oral para el tratamiento de la leishmaniasis. Biomédica 2006; 26(suppl.1):207-217.

26. Travi BJ, Tabares CJ, Cadena H. Leishmania (Viannia) braziliensis infection in two Colombian dogs: a note on infectivity for sand flies and response to treatment. Biomédica 2006; 26(Supl.1):249-53.

27. Rojas E, Morales C, Juárez E, Pineda N. Tratamiento de la leishmaniasis cutánea con plantas medicinales en Trujillo, Venezuela. Academia 2006; 19-25.

28. Marques P. Alterações de proteinograma em canídeos com leishmaniose antes e após tratamento. [Tesis de Maestría]. Lisboa: Universidade Lusófona de Humanidades e Tecnologias; 2014.

29.|Gómez-Ochoa P, Castillo JA, Gascó M, Zarate J], Alvarez F, Couto CG. Use of domperidone in the treatment of canine visceral leishmaniasis: A clinical trial. Vet J 2009; 179:259-263.

30. Sabaté D, Llinás J, Homedes J, Sustc $M$, Ferrer L. A single-centre, open-label, controlled, randomized clinical trial to assess the preventive efficacy of a domperidone-based treatment programme against clinical canine leishmaniasis in a high prevalence area. Prev Vet Med 2014; 115:56-63.

31. Fernandes CB, Junior JT, de Jesus C, Souza BM, Larangeira DF, Fraga DB, et al. Comparison of two commercial vaccines against visceral leishmaniasis in dogs from endemic areas: IgG, and subclasses, parasitism, and parasite transmission by xenodiagnosis. Vaccine 2014; 32(11):1287-1295. 
32. Wylie CE, Carbonell-Antoñanzas M, Aiassa E, Dhollander S, Zagmutt FJ, Brodbelt DC, Solano-Gallego L. A systematic review of the efficacy of prophylactic controlmeasures for naturally-occurring canine leishmaniosis, part I: Vaccinations. Prev Vet Med 2014; 117:7-18.

33. Nevot C, Rosa A, Eiras D, Estévez O. Actualidad en Leishmaniasis Canina. Vet Arg 2013; XXX(305):1-8.

34. Salomón OD, Mastrángelo AV, Santini MS, Ruvinsky S, Orduna T, Sinagra A, et al. Leishmaniasis visceral: senderos que confluyen, se bifurcan. Salud colectiva 2012; 8(supl.1):s49-s63.

35. Travi B. Ethical and epidemiological dilemmas in the treatment of dogs for visceral leishmaniasis in Latin America. Biomédica 2014; 34:7-12.
36. Passantino A, Russo $M$, Coluccio P. Canine leishmaniosis and eutanasia in Italy: a critical legal-ethical analysis. Rev Sci Tech 2010; 29(3):537-548.

37. Wylie CE, Carbonell-Antoñanzas M, Aiassa E, Dhollander S, Zagmutt FJ, Brodbelt DC, SolanoGallego L. A systematic review of the efficacy of prophylactic control measures for naturally occurring canine leishmaniosis. Part II: Topically applied insecticide treatments and prophylactic medications. Prev Vet Med 2014; 117:19-27.

38. Organización Mundial de la Salud (OMS). Control de la leishmaniasis. [on line] 2010. Serie de Informes Técnicos. URL Valida en: http:// apps.who.int/iris/bitstream/10665/82766/1/ WHO_TRS_949_spa.pdf 